\title{
RESEARCH Remittance in Rural Phewatal Watershed, Nepal
}

\section{Tek Bahadur Gurung}

ABSTRACT

KEY WORDS

Remittance

Watershed

Affluent

Destination

Variable
Subsistence farming yields only a limited amount of farm products does not meet the needs of the family in rural Phewatal watershed. Because of this, remittance has become an important source of cash income to the agro-based communities of the watershed. To meet their basic needs, leaving their family back home, the young which is 391 from 292 sample households, have gone abroad for jobs, They send approximately Rs 58226000 annually to their family. On average, each household receives approximately Rs 199000 per year; however, the average amount differs widely from nation to nation and community to community. Only a small size of people have gone to affluent countries and 74 p.c. of the total have gone to the Gulf region. Such type of foreign employment has made the distribution of remittance fairly uniform among the households. In addition to this, except in some cases, increasing number of foreign employees brings small positive changes on remittance amount of the households in Phewatal watershed.

NEPALESE GOVERNMENT FOLLOWED BY VARIOUS manpower agencies and organizations has been making its best efforts to improve the economic condition of rural Nepal through foreign employment; however, no remarkable change has been experienced in the rural economic life in Nepal. Since the majority of the rural communities have involved in agriculture, the government and various agencies had assumed improved farming as a major catalyst to overcome the economic problem of the rural communities. Considering it as a major factor, various agro development programs were lunched in Nepal during the by gone days. But the results are no longer satisfactory. Specially, rural communities in the hills and mountain are suffering from food-deficit. According to Upadhaya:

Agriculture not only drives the engine of growth, but also holds the main key to alleviation of poverty, which is pervasive and widespread. However, the growth of this has remained, at best, slow, and unstable during the past three decades; decades which mark the period of the Green Revolution. While many counters in Asia, including South Asia, were experiencing rapid gains in agricultural productivity the period, Nepal was most of the time struggling to maintain its previous productivity level. Consequently, 
Nepal's crop yields, which were the highest among the South Asian countries from 1961 - 1963, have now become the lowest in the region (Upadhyaya, 2000).

Government has introduced improved varieties of seeds, chemical fertilizer, and highbred cattle and sheep. Farmers use insecticides and pesticides to control plant diseases. J. N. Pandey (1988) has stated that a rowing emphasis on improving the technological base of agriculture and allied activities in Nepal. International transfer of technology in agriculture and allied activities primarily in the form of high yielding varieties of seeds, facilitated the orientation in policy for many of the countries involved apparently without their even having to go to the trouble of building up a viable research base indigenously. To help farmers raise the cattle successfully and control plant diseases, district or regional agricultural centers have managed junior technical assistants in the field. Tunnel farming in the hills and fruit farming (apple) in some parts of the Himalayas are the direct outcome of these efforts.

In spite of these efforts, rural economy remained marginal compelling the young to leave their native place for foreign jobs so that they can earn money as remittance in foreign land to support their family. "Increasing population, persistent poverty, and declining resources are leading to 'silent crises' - displacement of marginalized farmers and degradation of natural and land resources" (Baskota, Papola and Richter. 2000). Today, foreign employment is attracting the young like a piece of magnet attracting the tiny particles of iron in a pile of dirt. "Remittances play an important role in maintaining livelihoods during slack agricultural season, in view of the changing pattern of out migration - from temporary to permanent and single to family migration - whether remittances will continue to flow in as in the past needs to be examined" (Baskota, Papola and Richter. 2000).

Phewatal watershed comprises a number of rural communities and farming is their major source of living. A preliminary report of JICA (2001) states that approximately, 33 p.c. of the watershed (Phewatal) is classified as hill agricultural land. The average land tenure of Bari land and Khet land per household estimated to be 0.15 and 0.32 ha respectively and the cropping intensity is more than 200 p.c., which is quite higher than national average. It indicates that farmers are under pressure to use their farmland as intensively as possible to meet the increasing demand of food production. More than 70 p.c. of the households are suffering from food deficit for more than 9 months, "Economies of mountain areas have traditionally been dominated by subsistence agriculture. Limited non-food needs have mostly been met by remittances from out-migrants" (Papola, 2000). As stated by the government media, Nepal supplies at least 1500 to 2000 young people in the international labor market day by day. Recently, Nepal government has managed to facilitate free air ticket and other facilities to those who want to go abroad for foreign jobs, especially, to Malaysia, and the Gulf (Arabian) countries. Phewatal watershed is no longer exception in this context. The observation that the author has made in Phewa watershed reveals that the remittance is the major source of cash income to meet both basic and non basic needs of the rural communities.

\section{Purpose of the Paper}

In general speaking, remittances refers to a cash amount earned in foreign land and sent the same back home to the family for the living. In fact, remittance is related to economic (poverty), socio- 
cultural, political, educational and environmental condition of the communities. This paper does not assess the whole spectrum of the remittance at community level in rural Phewa watershed but describes the community level male and female foreign employment structure, average remittance amount, concentration pattern and relationship between the number of employees in foreign jobs and remittance amount.

\section{Location of Phewatal Watershed}

The watershed is situated in the middle part of Nepal with $28^{\circ} 7^{\prime} \mathrm{N}$ to $28^{\circ} 12^{\prime} \mathrm{N}$ and $84^{\circ} 7^{\prime} \mathrm{E}$ to $84^{\circ} 19^{\prime}$ E. (Fig. 1) The watershed is bounded by Sarankot Kaski Ridge in the north, Kalabang Ridge in the south, Panchasay Bhadauray Ridge in the west and northwestern edge of Phewatal in the east. It covers approximately $21 \mathrm{sq} \mathrm{km}$. Its east west and north south extensions are approximately $17 \mathrm{~km}$ and $7 \mathrm{~km}$ respectively. Some parts of six VDCs, namely Sarankot, Kaskikot, Dhikurpokhari, Bhadauri, Makanpur and Pumdi Bhumdi are included in the watershed. Specially, the watershed includes the area drained by two important rivers Harpan and Andheri Khola in Kaski district.

The upper part of the watershed known as high hill is covered by forest, and Pakho land in this part is used as pasture ground and hard crop cultivation (millet and corn), the hill is presided by Gurungs in upper part but Brahmans, Chettries, Dalits and other communities in the lower part. Bari known as the arable land used widely both for summer and winter crops (corn, and millets are summer crops and wheat is the winter crop). Bensi or Khet made of several terraces is the lower part of the hill extends up to the adjoining part of the Harpan valley. Except some isolated houses, this part is widely used for rice cultivation.

Harpan valley which is also called Phewa Phant is a narrow and leveled valley. The valley which is approximately two to seven $\mathrm{km}$ wide is made of the sediments deposited by River Harpan and Andher Khola.

The slope is gentle from northwest to southeast. Ghantichinna of Makanpur and Janmajaya Dunga of Dhikurpokhari VDC are the beginning points and Khapaudi is the ending point of the valley. The valley is traversed by River Harpan and the land is heavily used for rice cultivation. Except a few places at the adjoining parts of Kaski-



Figure 1: Phewatal Watershed, Nepal
Sarankot ridge, no human settlements have emerged in the valley.

\section{Sources and Analysis of Data}

A field survey of 560 households in 15 villages of six different VDCs (Table 1 and Fig.1) was conducted in May 2007. Of the total 560 households, slightly more than 52 percent, 
i.e., 292 households have a member or more in foreign employment. Table 2 indicates the caste level household number in the watershed. Dalit (schedule caste) household includes blacksmith, cobbler, and tailor master (54 households). The head or the active member of the household was requested to insert information on a provided questionnaire.

Information inserted on the questionnaire was entered into SPSS data editor, processed and transformed into the tables having totals, subtotals, proportions, percentages and averages. These figures are used to interpret the nature of remittance of the communities. In addition, the author has used two different statistical models, such as, index of concentration ( $\mathrm{C}$ index) and Pearson's product moment correlation coefficient $\left(\mathrm{r}_{\mathrm{yx}}\right)$. C index describes concentration patterns, such as, uniform and concentrated.

Uniform pattern describes the number of foreign employees and remittance amounts are evenly or uniformly distributed. The concentrated pattern describes the heavy concentration of remittance in a small proportion of foreign employees. Pearson's product moment correlation coefficient describes three possible relationships between the number of employees and the amount of remittance - positive, negative or no correlation. Positive correlation indicates reciprocal relation between the number of employees and the amount of remittance, negative correlation indicates the inverse relationship between the number of employees and the amount of foreign remittance and no correlation indicates no change in remittance amount when the number of employees changes.
Table 1: Sample villages with 560 households in Phewatal Watershed

\begin{tabular}{lccl}
\hline \multicolumn{1}{c}{ Village } & HH & Rmit_HH & \multicolumn{1}{c}{ VDC } \\
\hline Makanpur & 39 & 18 & Makanpur \\
Deorali & 45 & 23 & Kaskikot \\
Dharapani & 39 & 22 & Dhikurpokhar \\
Damdamay & 25 & 16 & Bhad-Tamagi \\
Chainpur & 57 & 39 & Bhad_Tamagi \\
Chapakot & 31 & 23 & Makanpur \\
Dharmadanda & 31 & 19 & Makanpur \\
Bhadauri & 20 & 8 & Bhad_Tamagi \\
Paudur & 7 & 4 & Dhikurpokhari \\
Ghantichina & 54 & 28 & Makanpur \\
Karkiko Tagaro & 25 & 13 & Kaskikot \\
Khapaudi & 41 & 3 & Sarankot \\
Padhalie & 59 & 34 & Sarankot \\
Chipchhipay & 44 & 22 & Kaskikot \\
Raikar & 43 & 20 & Kaskikot \\
Total & 560 & 292 & \\
\hline
\end{tabular}

Rmit $=$ Remittance $H H=$ Households

$V D C=$ Village Developement Committee

\section{Male and female population in foreign jobs}

There are 1777 people in 292 sample households in the sample villages (Table -1$)$ and average family size is approximately 6 persons per household. Of the total population, 391 i.e. approximately 22 per cent are involved in foreign jobs. Of the total 391 foreign job holders, 377 which is 96 p.c. are males and 14 (only 4 p.c.) are females. Of the total 14 female foreign job holders, 9 are from the Gurung community. 
Table 2: Male and female employees in foreign jobs

\begin{tabular}{lccccc}
\hline Caste & HH & Pop & M. jb & F. jb & Rm. jb \\
\hline Grg & 43 & 291 & 74 & 9 & 83 \\
Giri & 5 & 33 & 6 & 0 & 6 \\
Dalit & 54 & 312 & 68 & 1 & 69 \\
Brahman & 121 & 722 & 142 & 1 & 143 \\
Chetri & 48 & 290 & 60 & 2 & 62 \\
Newar & 2 & 13 & 2 & 1 & 3 \\
Magar & 19 & 116 & 25 & 0 & 25 \\
Total & 292 & 1777 & $(96$ p.c. $)$ & $(4$ p.c. $)$ & $(22$ p.c $)$ \\
\hline
\end{tabular}

$H H=$ Households, $P o p=$ Population,$j b=J o b$, $F=$ Females, $M=$ Male, $R m=$ Remittance, $p . c .=P e r$ cent.

\section{Employees in Foreign Employment}

Remittance amount differs widely from country to country. Generally, affluent countries pay more than developing countries but access to affluent countries is difficult financially and procedurally. Similarly, it is easy to go to those countries where Nepalese government has established diplomatic relation for foreign jobs. Distance also affects the foreign employment to some extent. Generally, increasing distance reduces the flow of people for jobs. In the case of Phewatal watershed, people have gone to India, USA, Europe, and East and Southeast Asia. Japan, Hong Kong and Malaysia are major destinations in East and Southeast Asia. The study shows Gulf nations as a major destination for jobs. Table - 3 indicates the nations with a number of employees from the watershed. Of the total 391 employees, 289 go to Gulf countries. This figure represents around 74 percent of the total foreign employees working in the Gulf region. East and Southeast Asia attract 48 (12 percent) and India attracts 40 (10 percent) of the total. Malaysia is the most important destination for foreign employment in
S/E Asia. Nations in European Union attract only 11 (3 percent) when US attracts only 3 (1 percent) employees respectively.

Table 3: Remittance in Rs from various regions and nations

\begin{tabular}{|c|c|c|c|c|c|c|}
\hline Caste & Ind & Arab sl & ESEA sl & US sl & EU sl & Total Rs \\
\hline Grg & $\begin{array}{l}8 \\
8 \\
\text { సે } \\
\end{array}$ & $\begin{array}{l}8 \\
\delta \\
o \\
\hat{n}\end{array}$ & $\begin{array}{l}8 \\
\frac{8}{n} \\
\frac{n}{2}\end{array}$ & 0 & $\begin{array}{l}8 \\
8 \\
0 \\
0 \\
0\end{array}$ & \begin{tabular}{l}
8 \\
8 \\
8 \\
\multirow{2}{*}{}
\end{tabular} \\
\hline Giri & $\begin{array}{l}\stackrel{8}{8} \\
\stackrel{+}{ \pm}\end{array}$ & $\begin{array}{l}\stackrel{8}{0} \\
\infty \\
\infty \\
\infty \\
n\end{array}$ & 0 & 0 & $\begin{array}{l}8 \\
8 \\
8 \\
8\end{array}$ & 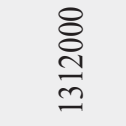 \\
\hline Dalit & 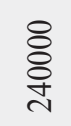 & 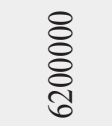 & 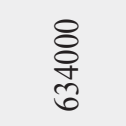 & 0 & 0 & 各 \\
\hline Brahman & $\begin{array}{l}8 \\
8 \\
\swarrow \\
\curvearrowleft\end{array}$ &  &  & $\begin{array}{l}8 \\
8 \\
8 \\
\text { ㅇ }\end{array}$ & $\begin{array}{l}8 \\
8 \\
8 \\
\infty \\
\text { m }\end{array}$ & 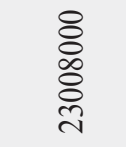 \\
\hline Chetri & $\begin{array}{l}\stackrel{8}{8} \\
\stackrel{8}{\sigma} \\
F\end{array}$ & $\begin{array}{l}8 \\
\text { ठ } \\
\text { त్ర } \\
\end{array}$ & 条 & $\begin{array}{l}8 \\
8 \\
8 \\
8\end{array}$ & $\begin{array}{l}\text { \&̊ } \\
\text { \&̊ }\end{array}$ & 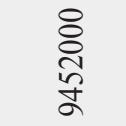 \\
\hline Newar & 0 & 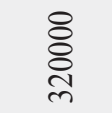 & 0 & 0 & 0 & \&ి \\
\hline Magar & $\begin{array}{l}8 \\
0 \\
\infty \\
\infty\end{array}$ & 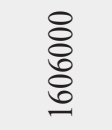 & 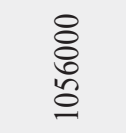 & 0 & 0 & $\begin{array}{l}8 \\
8 \\
8 \\
0 \\
0 \\
0\end{array}$ \\
\hline Total & $\begin{array}{l}8 \\
8 \\
\infty \\
\infty \\
0 \\
n\end{array}$ & 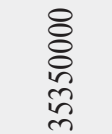 & $\frac{8}{\frac{8}{0}}$ & ষి & 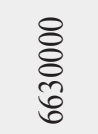 & 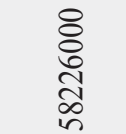 \\
\hline
\end{tabular}

Ind $=$ India, sl=salary, ESEA $=$ East and Southeast Asia, US=United States, EU=European Union

India as the nearest neighbor of Nepal was supposed to attract the largest proportion of employees but the study does not reveal it. The Gulf Region attracts the largest proportion of employees from Phewatal watershed. The major reason behind it is the legal and diplomatic relation of Nepal for manpower supply to this region. Korea and Malaysia are such East and Southeast Asian countries that have legally allowed Nepalese workers to hold some jobs. Compared to India, remuneration paid to the workers is high in these. The smallest proportion of employees in US and $\mathrm{EU}$ is mainly due to the immigration policy. 
Unlike the Gulf Nations, EU and USA have no policy to import workers from Nepal.

Table 4: Country cum region wise foreign employees

\begin{tabular}{|c|c|c|c|c|c|c|}
\hline $\begin{array}{l}\text { Country } \\
\text { Caste }\end{array}$ & 豩 & $\frac{\pi}{\frac{\pi}{0}}$ & 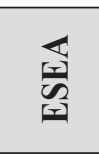 & US & $\mathbf{E U}$ & $\begin{array}{r}\text { Total } \\
\text { jb }\end{array}$ \\
\hline Grg & 2 & 58 & 18 & 0 & 5 & 83 \\
\hline Giri & 1 & 4 & 0 & 0 & 1 & 6 \\
\hline Dalit & 4 & 59 & 6 & 0 & 0 & 69 \\
\hline Brahman & 19 & 105 & 13 & 2 & 4 & 143 \\
\hline Chetri & 5 & 46 & 9 & 1 & 1 & 62 \\
\hline Newar & 0 & 3 & 0 & 0 & 0 & 3 \\
\hline Magar & 9 & 14 & 2 & 0 & 0 & 25 \\
\hline Total & $\begin{array}{c}40 \\
(10 \mathrm{pc})\end{array}$ & $\begin{array}{c}289 \\
(74 \text { pc. })\end{array}$ & $\begin{array}{c}48 \\
(12 \mathrm{pc})\end{array}$ & $\begin{array}{c}3 \\
(1 \mathrm{pc})\end{array}$ & $\begin{array}{c}11 \\
(3 \mathrm{pc})\end{array}$ & 391 \\
\hline
\end{tabular}

\section{Remittance Distribution Pattern}

Total amount ofremittance that comes as remittance from the Gulf nations, East and Southeast nations followed by India per year is approximately Rs. 58226000.0 in Phewatal watershed (Table-4). Of the total remittance amount, the largest share (61 p.c.) goes to the Gulf region. Since the largest proportion of workers from the watershed moves to this region, it also receives the largest amount of total remittance from this region. After the Gulf region, the watershed receives the second highest amount of remittance (Rs. 9661000) from the nations in East and Southeast Asia. The watershed receives about 16.59 percent of its total remittance from these regions. The watershed gets the third largest amount of remittance (Rs. 6630000.00 about 11.39 p.c.) from European nations. As opposed to a small proportion of employees (approximately 3 p.c.), the watershed receives more than 11 p.c. of its total remittance from EU. Likewise, US that shares approximately 1 percent of the total employees shares about 5 percent of the total remittance of the watershed. The remittance from India represents approximately 6 percent of the total although more than 11 percent of the total employees from the watershed move to this nation.

\section{Average Amount of Remittance in Phewatal Watershed}

Average amount of remittance by caste and nation gives an idea on nature of remittance distribution in Phewatal watershed. The overall average household cash income is approximately Rs 199404 in the watershed. In an agrarian community, this amount is considered as an important source of cash income to the family. However, it differs widely from community to community. Of the total nine communities, Gurung households have the highest average followed by the Giri community. Except a cobbler household, all the other communities have the average amount of cash income more than Rs 100000 from the foreign jobs.

Table 5: Household average amount of remittance in Rs.

\begin{tabular}{|c|c|c|c|c|c|c|}
\hline Caste & $\begin{array}{l}\text { Ind } \\
\text { avg }\end{array}$ & $\begin{array}{c}\text { Arab } \\
\text { avg }\end{array}$ & $\begin{array}{c}\text { ESEA } \\
\text { avg }\end{array}$ & $\begin{array}{c}\text { US } \\
\text { avg }\end{array}$ & $\begin{array}{l}\text { EU } \\
\text { avg }\end{array}$ & Total \\
\hline Grg & 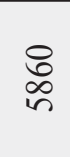 & $\begin{array}{l}\vec{\infty} \\
\stackrel{0}{b} \\
=\end{array}$ & 辛 & 0 & 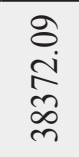 & $\begin{array}{l}n \\
0 \\
\infty \\
= \\
=\end{array}$ \\
\hline Giri & 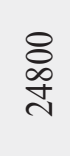 & $\begin{array}{l}\stackrel{8}{8} \\
\stackrel{\Xi}{=}\end{array}$ & 0 & 0 & 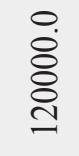 & 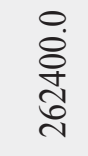 \\
\hline Shoe_m & ষి & 0 & 0 & 0 & 8 & $\begin{array}{l}8 \\
\text { षे } \\
8 \\
8\end{array}$ \\
\hline Brahman & ¿্ & $\begin{array}{l}n \\
\infty \\
ٍ \\
0\end{array}$ & $\underset{\mathbb{N}}{\overleftarrow{\Delta}}$ & $\begin{array}{l}\stackrel{n}{\cong} \\
\stackrel{\sigma}{\sigma}\end{array}$ & 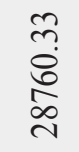 &  \\
\hline Chetri & $\widehat{\infty}$ & $\begin{array}{l}\tilde{\hat{~}} \\
\text { సิ }\end{array}$ & 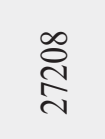 & $\begin{array}{l}\stackrel{8}{0} \\
\cong\end{array}$ & $\begin{array}{l}8 \\
0 \\
0 \\
\infty \\
\infty\end{array}$ & 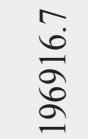 \\
\hline Black-smith &  & 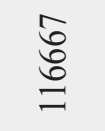 & $\begin{array}{l}\stackrel{\infty}{\sim} \\
\stackrel{\sim}{=}\end{array}$ & 0 & 8 & $\begin{array}{l}\text { ڤె. } \\
\text { ర్ } \\
\text { }\end{array}$ \\
\hline
\end{tabular}




\begin{tabular}{|c|c|c|c|c|c|c|}
\hline Caste & $\begin{array}{l}\text { Ind } \\
\text { avg }\end{array}$ & $\begin{array}{c}\text { Arab } \\
\text { avg }\end{array}$ & $\begin{array}{c}\text { ESEA } \\
\text { avg }\end{array}$ & $\begin{array}{l}\text { US } \\
\text { avg }\end{array}$ & $\begin{array}{l}\text { EU } \\
\text { avg }\end{array}$ & Total \\
\hline Tailor & 0 & $\begin{array}{l}8 \\
\text { ᄋ్ } \\
\text { ( }\end{array}$ & 0 & 0 & 8 & $\begin{array}{l}\text { ㅇ. } \\
8 \\
8 \\
8 \\
\text { ㅇ }\end{array}$ \\
\hline Newar & 0 & $\begin{array}{l}8 \\
8 \\
8 \\
0\end{array}$ & 0 & 0 & 8 & $\begin{array}{l}\stackrel{0}{8} \\
8 \\
8 \\
8\end{array}$ \\
\hline Magar & $\begin{array}{l}8 \\
\stackrel{8}{1} \\
\text { గి }\end{array}$ & 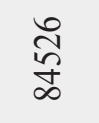 & $\begin{array}{l}\frac{2}{\hat{n}} \\
i n \\
n\end{array}$ & 0 & 8 & 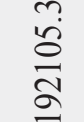 \\
\hline Total &  & 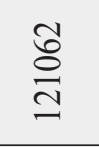 & $\begin{array}{l}\text { D } \\
\text { o } \\
\text { లె }\end{array}$ & 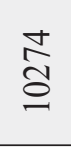 &  & $\begin{array}{l}\text { 方 } \\
\text { \& } \\
\text { 。 }\end{array}$ \\
\hline
\end{tabular}

\section{Remittance Distribution Pattern}

Two different variables, number of employees and amount of remittance in thirteen nations and the Gulf region are used in this device to describe the concentration pattern of remittance in the watershed. The author assumes the increasing number of employees increases the amount of remittance and vice versa. The author has used a simple device called index of concentration written as $C=1 \square R_{1}$ to test this assumption. The symbol $\mathrm{C}$ refers to index of concentration, and $R_{1}$ refers to proportion of remittance. It also uses a symbol $\mathrm{E}$ for the number of employees. The index is based on ratios of the proportion of remittance and the proportion of employees. For this, at first proportion of employees followed by the proportion of remittance are calculated. The device, $\frac{E_{i}}{E_{i}}$ and $\frac{R_{i}}{R_{1}}$ computes the proportions. Since the proportions of $\mathrm{E}$ is related to the proportion of R, the following device, $\frac{\frac{R_{i}}{R_{T}}}{E_{i}}$ shows the ratios between remittance and employment of the nations (Table-4, col-6). These values are helpful to rearrange the remittance amount with employment figures in an order is called Location Quotient (L.Q.). Rearrange the values according to their L.Q. Calculate the cumulative figures of $\mathrm{E}_{\mathrm{i}}$ and $\mathrm{R}_{\mathrm{i}}$ as arranged by L.Q. It shows the cumulative figures of $\mathrm{R}_{\mathrm{i}}$ over and below 0.50 and the cumulative of $\mathrm{E}_{\mathrm{i}}$ that corresponds to 0.50 proportion of $\mathrm{R}_{\mathrm{i}}$. A simple device $W=0.06138+X$ where $\mathrm{W}$ refers to the value equal to 0.50 proportions of $\mathrm{R}$ and $\mathrm{X}$ refers to the value between 0.0613 and W. C value close to 1 shows the concentration of remittance to a small proportion of employees and the value close to 0.50 shows uniform pattern of remittance distribution.

Table 6: Country/region wise employment and remittance proportion

\begin{tabular}{|c|c|c|c|c|c|c|c|}
\hline $\begin{array}{c}\text { Country/ } \\
\text { Reg }\end{array}$ & Rmt_rs & 言 & $\begin{array}{r}\text { Rmit } \\
\text { pro }\end{array}$ & $\begin{array}{r}\text { Emp } \\
\text { pro }\end{array}$ & L.Q. & $\begin{array}{c}\text { Rmit_ } \\
\text { cum }\end{array}$ & $\begin{array}{c}\text { Emp_ } \\
\text { cum }\end{array}$ \\
\hline Japan & 1200000 & 1 & ठั. & ڤัे &  & .0206 & .00256 \\
\hline Switzerland & 1200000 & 1 & ठั. & 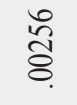 & $\begin{array}{l}\mathscr{\infty} \\
\mathscr{\infty} \\
\infty \\
\infty\end{array}$ & .0412 & .00512 \\
\hline USA & 3000000 & 3 & $\frac{n}{n}$ & $\begin{array}{l}\hat{0} \\
\text { के. }\end{array}$ & $\underset{\frac{n}{n}}{\overparen{\sigma}}$ & .0927 & .01279 \\
\hline Belgium & 1800000 & 2 & के & $\frac{1}{8}$ & $\underset{\tilde{\sigma}}{\tilde{\delta}}$ & .1237 & .01790 \\
\hline Nitherand & 1380000 & 2 & ฮิ & $\frac{1}{8}$ & $\begin{array}{l}\tilde{\approx} \\
\tilde{b} \\
+\end{array}$ & .1474 & .02302 \\
\hline Germany & 600000 & 1 & $\frac{\%}{0}$ & ڤัे & बें & .1577 & .02558 \\
\hline Hong Kong & 2640000 & 5 & f̊ & 气ે & 点 & .2030 & .03836 \\
\hline Tiwan & 1460000 & 3 & ฮे. & $\begin{array}{l}5 \\
8 \\
8\end{array}$ & $\begin{array}{l}\overline{\mathbb{a}} \\
\underset{\sim}{n}\end{array}$ & .2281 & .04604 \\
\hline UK & 1650000 & 5 & ठి. & 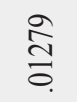 & 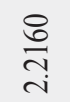 & .2564 & .05882 \\
\hline Korea & 200000 & 1 & छे. & ڤั & 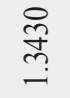 & .2598 & .06138 \\
\hline Gulf_nations & 35350000 & 289 & $\overline{\mathrm{s}}$ & $\frac{m}{2}$ & $\underset{\infty}{\stackrel{\Xi}{\Delta}}$ & .8670 & .80051 \\
\hline Malysia & 4161000 & 38 & $\frac{n}{5}$ & $\frac{2}{8}$ & $\approx$ & .9384 & .89770 \\
\hline India & 3585000 & 40 & 웅. & ฮ్రి & $\frac{a}{8}$ & 1.0000 & 1.00000 \\
\hline
\end{tabular}

Pro=proportion, L.Q.=location quotient, cum $=$ cumulative, Emp=employment 


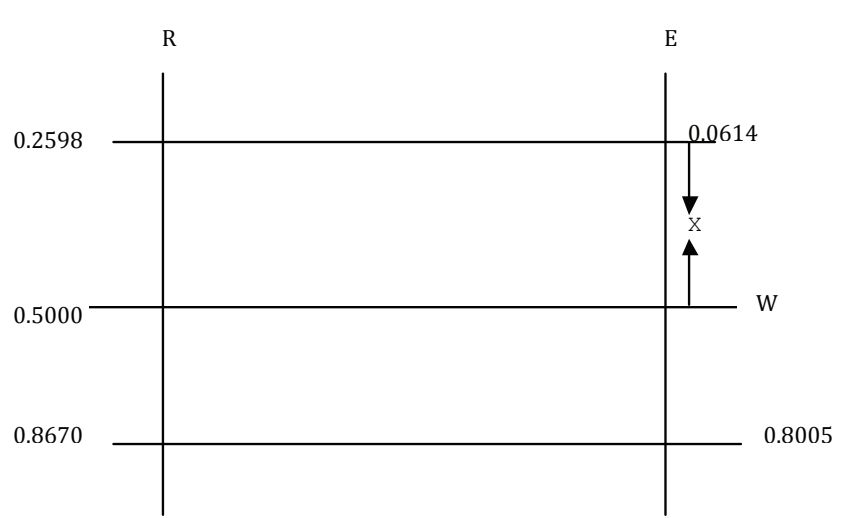

$\mathrm{W}=0.0614+\mathrm{X}$

$\frac{0.05000-0.2598}{0.8670-0.2598}=\frac{X}{0.8005-0.0614}$

$\frac{0.24}{0.61}=\frac{X}{0.74}$

$0.61 X=0.24 * 0.74$

$0.61 \mathrm{X}=0.18$

$\mathrm{X}=\frac{0.18}{0.61}=30$

$\mathrm{W}=0.0614+0.30=0.36$

$\mathrm{C}=1-0.36=0.64=64 \%$

Calculated cumulative value (Table-4 in col.7) of index of concentration (C) depicts 0.5000 the proportion of remittance lies between 0.2509 and 0.8670 . Similarly, cumulative value of employees that corresponds to 0.5000 lies at W, i.e., $\mathrm{X}+0.0614$ which is $0.30+0.0614$ is 0.36 . Since $C=1-0.36=0.64$ lies between 0.50 and 0.75 the remittance distribution pattern seems moderately uniform, i.e., except a few employees, a large number of employees send almost the same amount of remittance back home to the family.

\section{Relationship between the Number of Employees and Remittance Amount}

A statistical model called correlation coefficient is widely used to indicate the relationship between two different variables. Statistically, it is written

as

$$
R y x=\frac{n \sum x y-\sum x \sum y}{\sqrt{\left[n \sum x^{2}-\sum(x)^{2}\right]\left[n \sum y^{2}-\sum(y)^{2}\right]}}
$$

where $r$ refers to coefficient of correlation, $x$ and $y$ refer two different variables, and $n$ refers to the number of observations. The result always ranges between -1 and +1 indicating perfect negative to perfect positive relationship respectively. Zero that lies between -1 and +1 indicates no relation or no cause and effect relationship. In this study, remittance (R) and employees (E) are two different variables. The author assumes that the increasing number of employees increases the amount of remittance and vice versa. Software called SPSS (statistical package for social scientists) has processed the data provided by 292 sample households of the watershed. The result given by Pearson's product moment correlation coefficient $\left(\mathrm{r}_{\mathrm{yx}}\right)$ is +0.335 (see computed values below). Since the result is positive but close to ' 0 ', there is a very weak positive correlation between the distribution of number of employees and the remittance amount in the watershed. In other words, proportion of change in remittance is small although the proportion of change in foreign employment is large. Squared value of $r_{y x}$ gives coefficient of determination explaining the proportion or percentage of variation in remittance due to the change in number of foreign employees. $\mathrm{r}_{\mathrm{yx}}^{2}$ is 0.112 or 11.20 p.c., i.e., about 11 percent variation in remittance is due to the changes in the number of foreign employees in Phewatal watershed. There are other factors such as distance, salary level, etc. affecting changes in remittance in the watershed.

\begin{tabular}{cccc}
\hline & & Rmit_Rs & Foreign Employees \\
\hline $\begin{array}{c}\text { Pearson Cor- } \\
\text { relation }\end{array}$ & $\begin{array}{c}\text { Remit- } \\
\text { tance_Rs } \\
\text { Foreign }\end{array}$ & 1.000 & $\mathbf{. 3 3 5}$ \\
& $\begin{array}{c}\mathbf{3 3 5} \\
\text { Employees }\end{array}$ & 1.000 \\
Sig. (1-tailed) & RMT_RS &. & .000 \\
& FRN_JB & .000 &. \\
N & RMT_RS & 292 & 292 \\
& FRN_JB & 292 & 292 \\
\hline
\end{tabular}

Model Summary

\begin{tabular}{ccccc}
\hline Model & $\mathrm{R}$ & $\begin{array}{c}\mathrm{R} \\
\text { Square }\end{array}$ & $\begin{array}{c}\text { Adjusted } \\
\text { R Square }\end{array}$ & $\begin{array}{c}\text { Std. Error of the } \\
\text { Estimate }\end{array}$ \\
\hline 1 & $\mathbf{. 3 3 5}$ & .112 & .109 & 235785.4451 \\
\hline
\end{tabular}






Figure 2: Relationship between foreign employment and remittance amount

\section{Conclusion}

Farming which is traditional and subsistence type in Phewatal watershed is the major source of livelihood to the rural communities. Farm produces are insufficient to meet the basic needs of the family. Cash crop farming and employment opportunities for income generating are limited. This situation has compelled the rural communities to explore the opportunities that help them to tackle the financial problem of the family. More than 52 percent of the households in the watershed have a member or more in foreign job to support the family. In addition to this, foreign employment absorbs a large proportion (22 p.c.) of active population of the remittance earning households in Phewatal watershed. In other words, the rural communities are losing a considerable proportion of able population day by day in the watershed. This process has created the shortage of able manpower in the watershed. Its direct impact is seen on increasing amount of fallow land day by in the watershed.

A huge gap between the proportions of male and female employees clearly states the depletion of males more than the females. Tradition has prohibited females leaving the family for foreign jobs. Small proportion of females in foreign jobs for remittance indicates the emergence of new trend. In the fast changing world, there is no need to wait for a long time to have the equal proportion of male and female population in foreign jobs.

The average amount of remittance per household is Rs 199404.1 depicts foreign employment as an important source of cash income to the rural communities in Phewatal watershed. Toady, remittance has become so popular that life is financially easy once the households have one or more members outside in foreign jobs. Unemployment is a major problem of rural agrarian communities. Since the household average amount of remittance ranges from Rs 60000 to over Rs 300000, remittance or foreign employment has become an important charm to the people in the watershed.

The result based on 'c' index depicts the moderately uniform in remittance distribution. Although the proportion of remittance is large from the western countries, the proportion of employees is so small that the effect on overall concentration of remittance is only a little. On the other hand, the proportion of employees and remittance in the Gulf countries and Malaysia is so large that that has pulled the distribution pattern towards moderately concentrated. Some reasons behind this are related to easy access, process, cost, job availability, manpower companies, and wages.

Weak positive correlation between the number of employees and the amount of remittance is due to a large variation on average amount of remittance. The regression line that rises with a small acute angle depicts a large increase in foreign employment increases a small amount of remittance. In fact, coefficient of determinant $\left(\mathrm{r}^{2}\right)$ which is 0.11 or 11 percent depicts no much effect 
of number of employees on changes on changing pattern of remittance. Such a mall percentage of change is due to a large number of employees

\section{REFERENCES}

Upadhyaya, H. K. 2000. Sustainable poverty alleviation and mountain development in Nepal: Status, experience and strategy. In growth, poverty alleviation and sustainable resource management in the mountain areas of South Asia: Proceedings of the international conference held from 31st January - 4th February 2000 in Kathmandu, Nepal. Edited by Mahesh Baskota, Trilok s. Papola and Jurgen Richter. $172-195$.

Feldafing, Germany: German Foundation for International Development and International Center for Integrated Mountain Development

Pandey, J.N. 1988. A Strategy of Rural Development. In Commercial Activities and Rural Development in South Asia; A Geographical Study, edited by V.K. Shrivastava, 141-449. New Delhi: Concept Publishing Company

Baskota, M., Trilok S. P. \& Jurgen Richter. 2000. Development in mountain areas of Soth Asia - issues and options. In growth, poverty alleviation and sustainable resource management in the

Tek Bahadur Gurung is an Associate Professor in Department of Geography at Prithvi Narayan Campus, Pokhara, Nepal. He has 37 years of experience in teaching. He published about a involved in low paid jobs in Malaysia and Gulf Countries and on the other hand, only a few in well paid jobs.

mountain areas of South Asia: proceedings of the international conference held in Kathmandu, Nepal from 31st January - 4th February 2000, edited by Mahesh Baskota, Trilok S. Papola and Jurgen Richter, 31 - 56. Kathmandu, Nepal: German Foundation of International Development and International Center for Integrated Mountain Development.

Japan International Cooperation Agency (JICA). 2001. Interim Report on the Development Study on the Environmental Preservation of Phewa Lake in Pokhara, Nepal. Kathmandu: JICA, Nepal Office.

Papola, T. S. 2000. Enterprise development for poverty alleviation with sustainable resource management: trends, experiences and polices in the HKH region. In proceedings of the international conference on growth, poverty alleviation and sustainable resource management in the mountain areas of South Asia, held from 31 January to 4 February 2000 in Kathmandu, Nepal. Edited by Mahesh Banskota, Trilok s. Papola, and Jurgen Richter; 321 - 348. Kathmandu: German Foundation for International Development.

dozen of research articles and presented half dozen papers. His area of interest in research is especially economic geography. 